E 99

.E7 A5 



AMERICAN MUSEUM OF NATURAL HISTORY

Stokes Paintings represent $=$ ing Greenland Eskimo

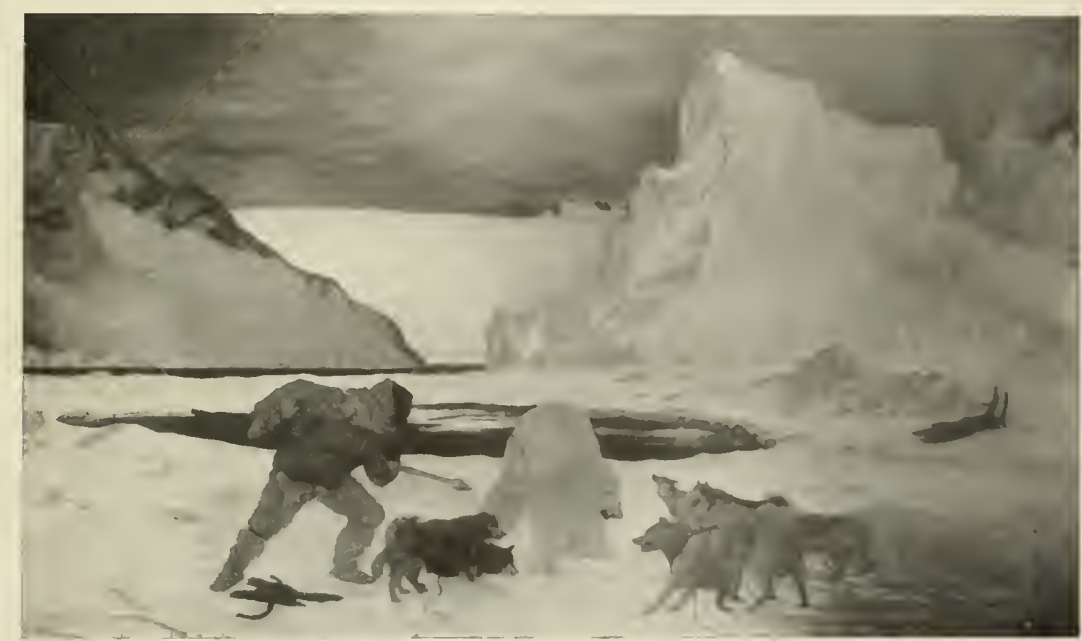

GUIDE LEAFLET NO. 30

NOVEMBER, 1909 


\section{American Museum of Natural History \\ Serenty-seventh Street and Central Park West, New York City \\ BOARD OF TRUSTEES}

Presilent

First l'ict-l'resilent

Hexry Fabrield U-Bor.:
J. Pierpust Mokgan

Treasurer

CIIARLE; I.ANIER

Ex Officio

Second I"ice-President

C'levelavd H. Dodge

Secrelary

J. HaMPDEN ROBB

THE, MAYUR OF THE City OF NEW JORK

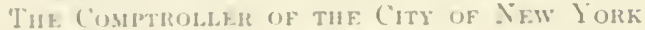

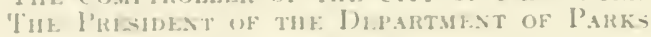

Class of 1909

JUELI'H H. (HO). TL

J. JIERPONT MORG.A.

IIENRY F. OSBORN

Class of 1910

J. H.T.MPDE: IR(OBB

ARTHER C'LTISO J.AMES

Class of 1911

CII.RRLES L.INIER

A. IOU. W. H.IRI)

S1:TH I.UW

Class of 1912

1). (1). $1111.1 . \mathrm{S}$

ARCHIHALI R ROCiliRs

AJRIAN ISELIN, JR.

PEIRCY R. PINE

J)IIN B. TIEVUR

WILLIAM ROCKEFELLER

GUS'IV E. IIISSEL
ALBIST S. BICKMORE

CURAELIL: C. CUYLER *

Class of 1913

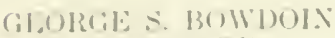

1. 1). J[II,I.I.IRI)

(I.FVIJ.AND H. DODGG

- RCHER M. HUN"TINGTON

\section{EXECUTIVE OFFICERS}

birectur

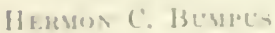

Assistunt-iecretary und Assistant-Treasurer

Giromit: H. SHEKWOUD

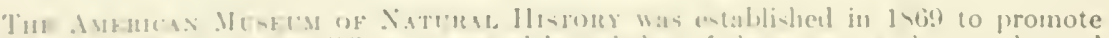

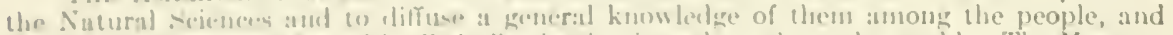

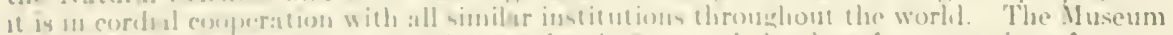

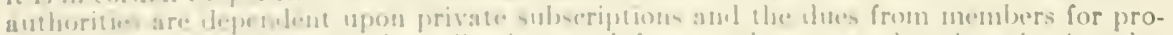

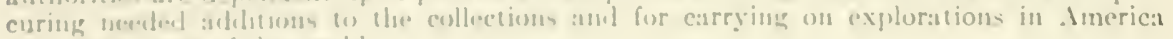
ame other parte of the world

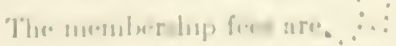

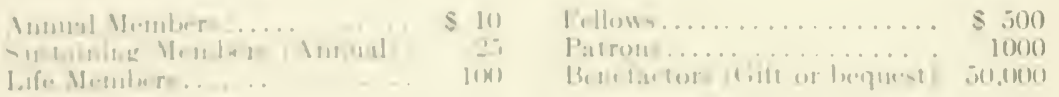

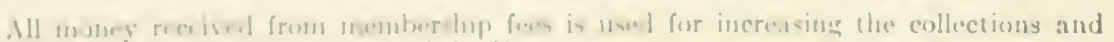

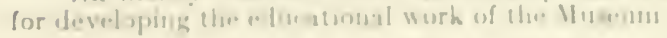

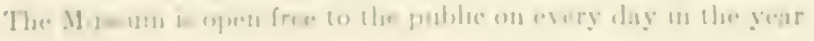




\title{
The Stokes Paintings Representing Greenland Eskimo
}

\section{A DESCRIPTION OF THE \\ MURAL DECORATIONS OF THE ESKIMO HALL}

GIVEN TO THE

\author{
American Museum of Natural History \\ BY
}

ARTHUR CURTISS JAMES

No. 30

OF TH:

GUIDE LEAFLET SEf?:QS

OF TII:

AMERICAN MUSEUM OF NATURAL HISTORY

EDMUND OTIS HOVEY, EOITOR

New York. Published by the Museum. November, 1909 


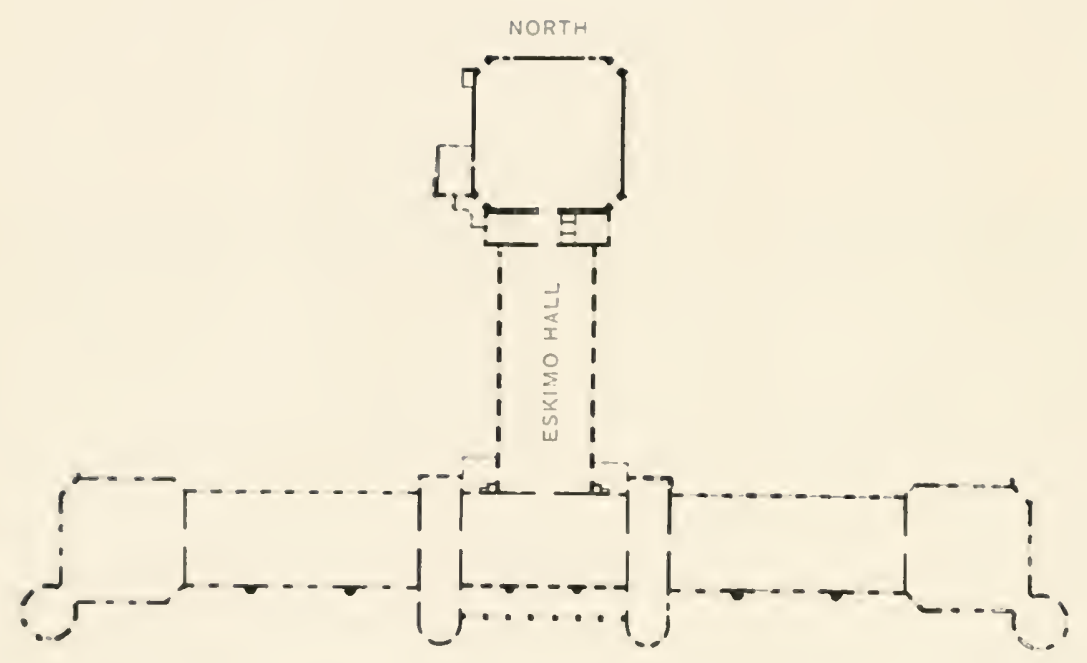

Floor plan of the ground floor of the Museum, showing the location of the Eskimo Hall, where are displayed the Stokes paintings presented by Mr. Arthur Curtiss James.

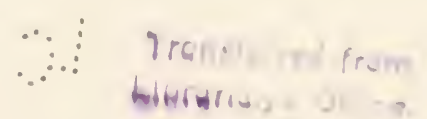




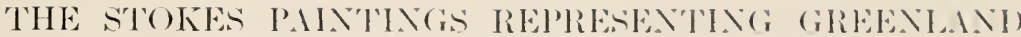 EसLIR.}

$\mathrm{T}$

HE mural decorations at the morthera end of the Eskimo Hall latre been painted by Mr. Frank Willuert Stokes, an allist, who, as menber of the Peary Relief Expedition of $1 \$()^{2}$ and of the Peary North Greenland Expedition of 1893 and 1894 , has made ardeful sturly of the

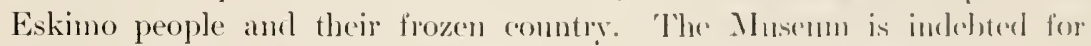
these paintings to Mr. Arthur Curtiss James, one of the 'T'rusteres.

Ranged about the hall below are the weapons, the articles of dress, the boats, the sleds, while above them in this painted friege these same objeets are seen put to use in the daily activities of the Eskino, revealing his adaptation to an enviromment of months' long dily and nights among glaciers and icebergs. 'The combination of the seitutific exhithts below and the artist's work above, brings home to the observer not only the ethnological facts involved, but also other facts, such as the ansterity of Eskimo life, its enforcel simplicity and the limitations set upon civilizattion for the people of the Aretics. Much of the interest of these pietures rests in the fact that many of the scenes represent localities anctually visited by the artist. Mr. Stokes established his studio at Bowdoin Bay, $77^{\circ}+t^{\prime}$ $\therefore$. katitude, and worked there during fourteen months, with the primitive life of the Eskimo and the glowing colors of the northern land moder constant observation. As William Walton has said in an article in Scribner's Magazine for February, 1909, Mr. Stokes has here suceected, despite the inalequaey of pigments, in well suggesting "the utmost splendor" of light that blazes in the Polar skies and glows in the Polar, transherent ien."

\section{The North Mis..}

'The largest picture of the series - in full view from the main forer of the Museum - is a contimmons panomamal sixty leet long. It is intense and realistic in its coloring. In the center the glow of a minnight sum illuminates promontories and seal, towallel the right this hrilliant color gradually fanles to the gray amel purple of the twilight that precedes the long Aretic night, while towallel the loft it changese to the white lights and alepe bhe shatows of that of her twilight that forededls the approach of the long Iretice day. 


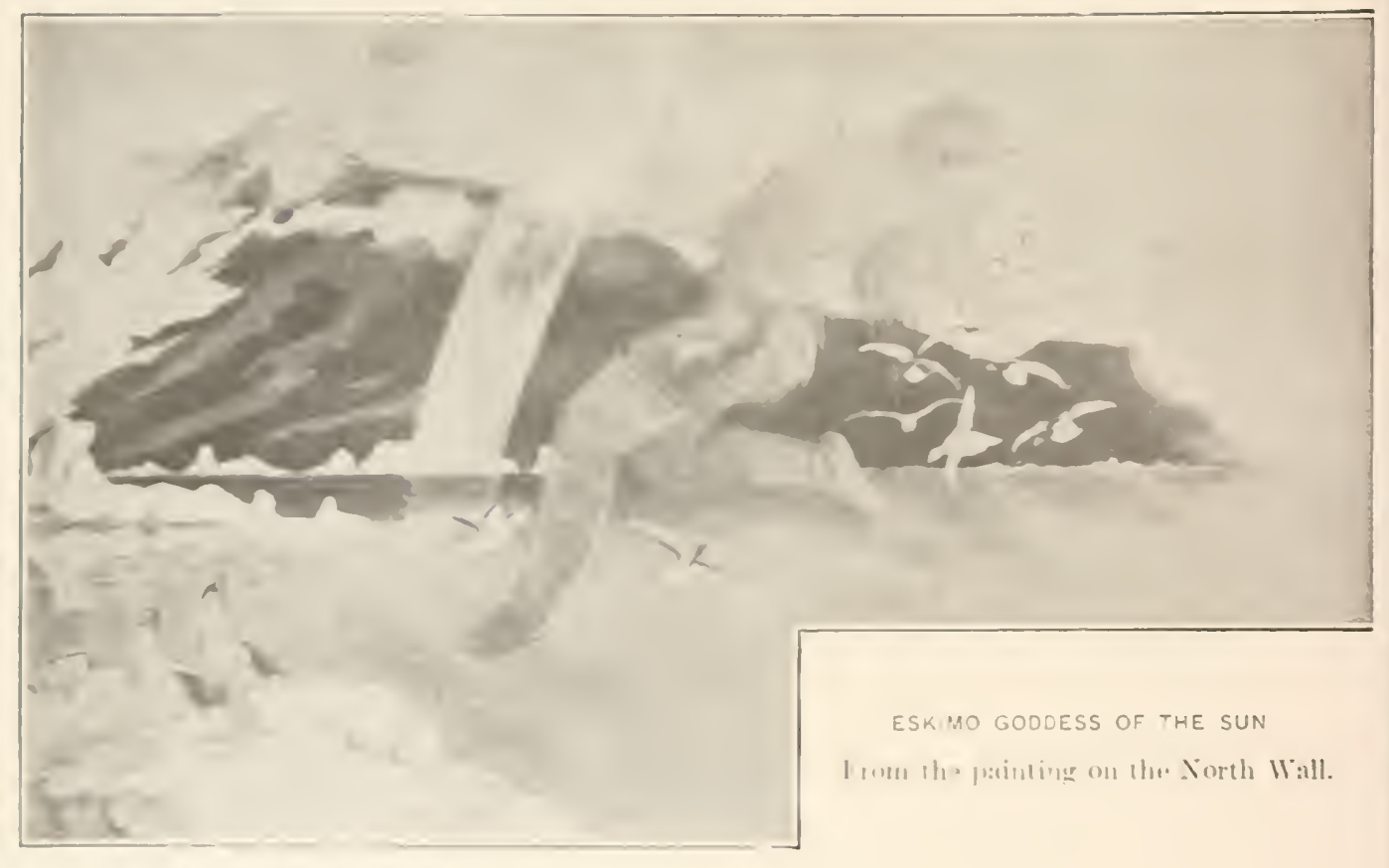

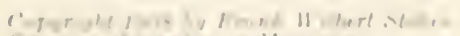

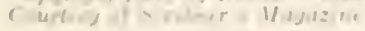

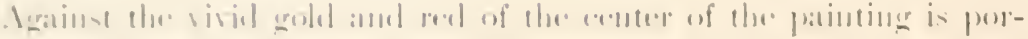

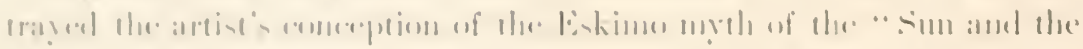

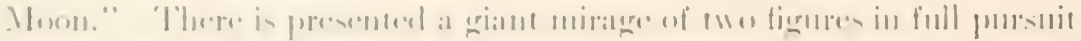

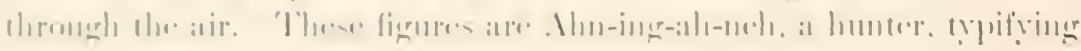

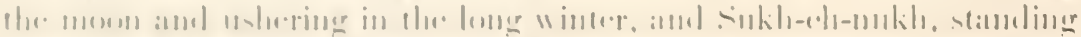

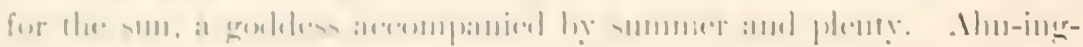

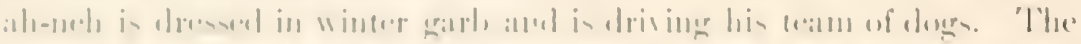

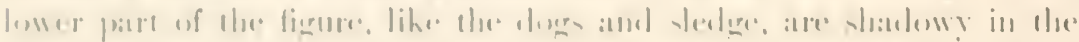

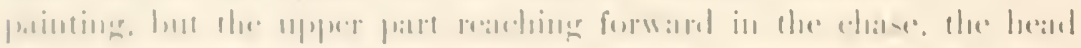

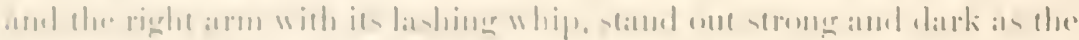

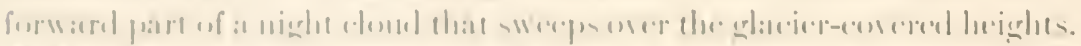

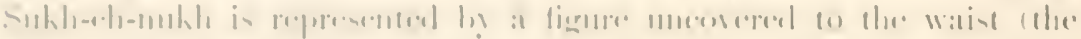

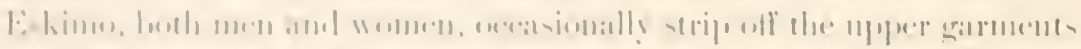

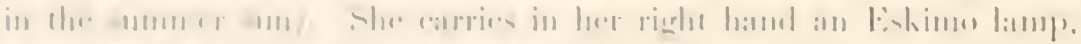

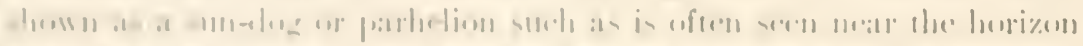

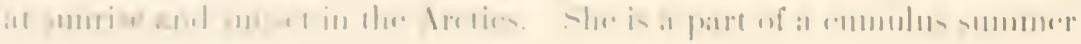




\section{HASTEN}

PRINTED CARDS ORDERED

delivered to talog Division

should reach inting Office later than sep $9 \quad 1912$ 



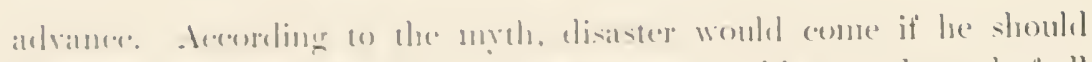

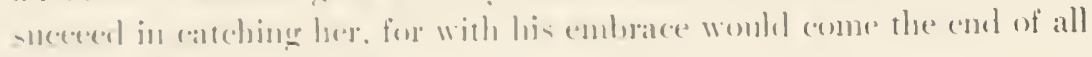
dhinger.

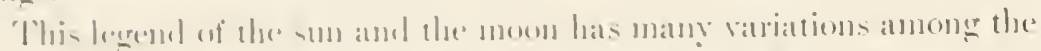

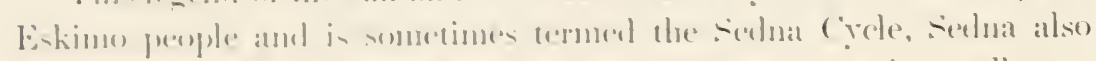

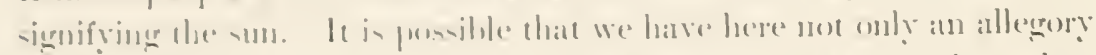

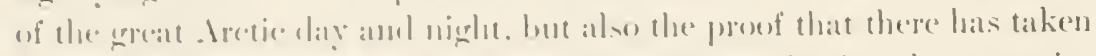

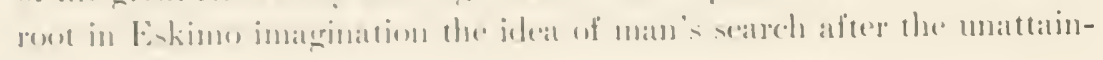
allie.

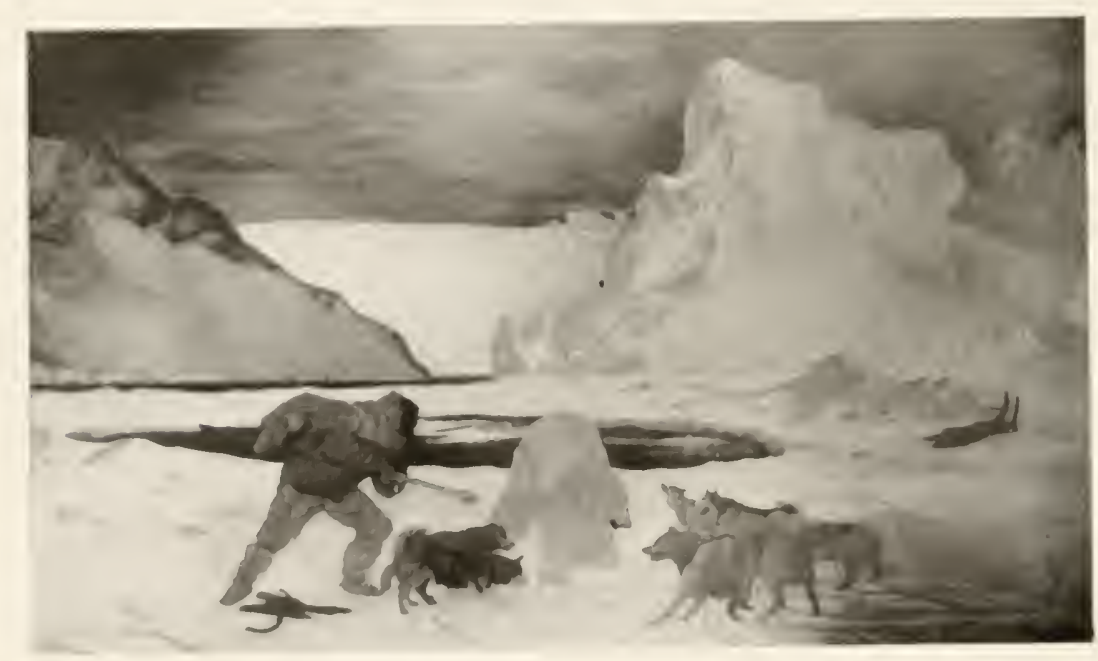

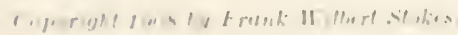

POLAR BEAR AT BAY

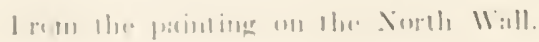

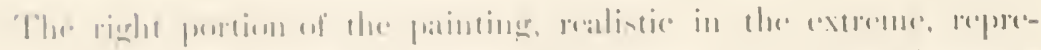

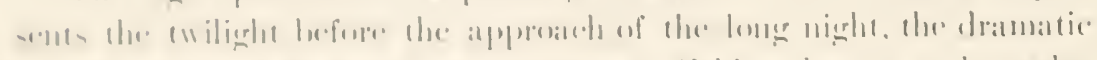

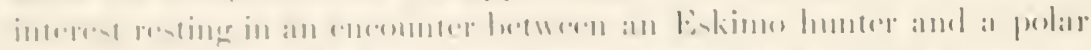

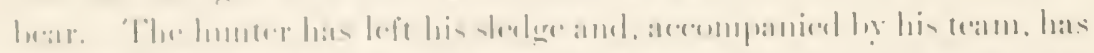

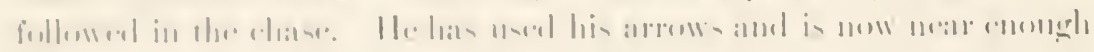

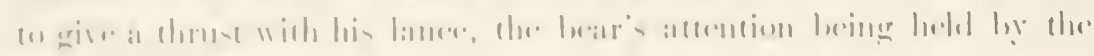
low.

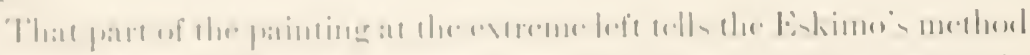

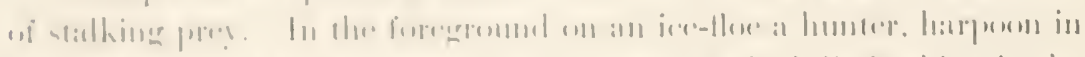

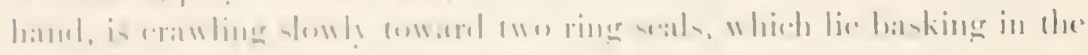


sun near their hole. Eskimo hunters have great skill in griving decoy sounds. They can make cantious apploach to gulls hy waving a grull's wing in the air, while whistling the bird's notes; they can allay the suspicions of seals by lying flat on the ice and waving a foot in initation of a seal's head, while giving the characteristic calls of the seals. Beyond the seal hunter in the distanee rises above the ice of the glacier, a bell-shaped elevation of land which the Eskimo knows as a "munatak." Still farther to the left towers an iceberg, while over all is the dawning light of the summer that is being ushered in by sukh-ell-nukh, the sun goddess.

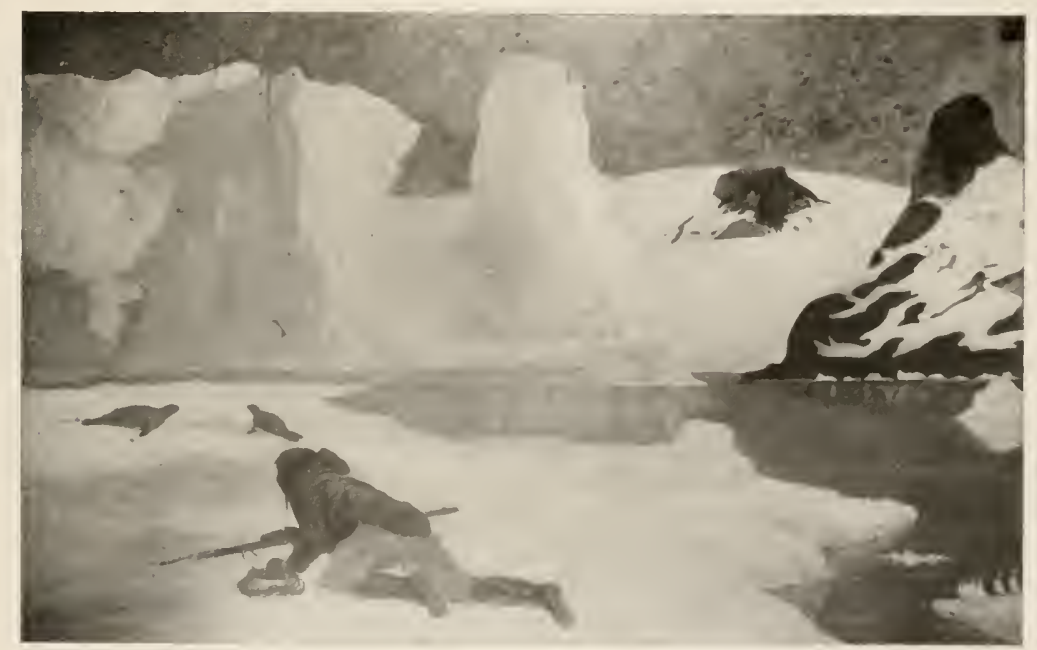

Copyright 1908 by Frank Wilbert Stokes.

ESKIMO STALKING THE SEAL.

From the Painting on the North II:all.

THE HAST WIL.

The first or northern panel - .1n Immit Encampment in Latr. Intumn.

Pictures of actual erents in Eskime life atre eontinued on the arat and west sides of the hall, the unity of the compositions heinger gamed by making the sky line in the east and west patmels the same als that of the 
painting on the nomb wall. The there pands on the eatst watl countinule

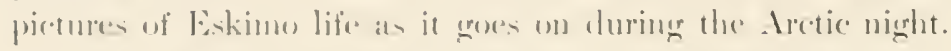

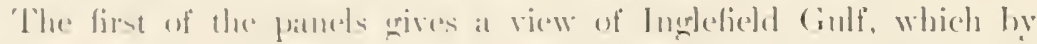

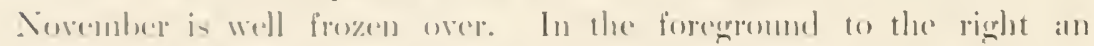

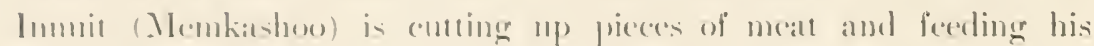

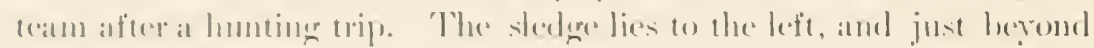

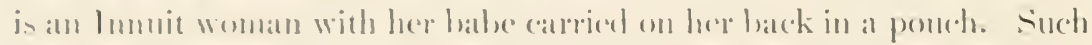
a pouch is mate of fox stin amel is a part of the hooded upper gramenest.

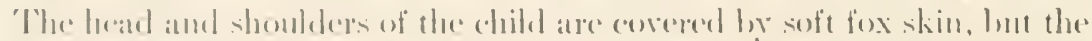

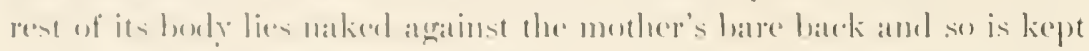

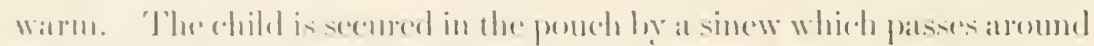
its buly and aromed the upper patrt of the mothere satist.

I linle Immit hoy stamb hy his mother, watching his playmate, an

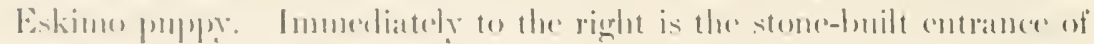

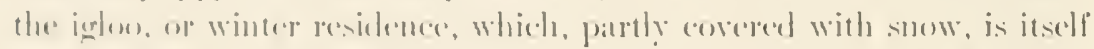

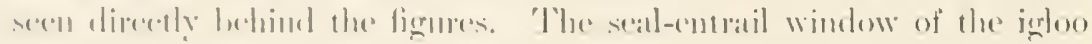
revals a pale light fom the lamp within, a latup which must serve the

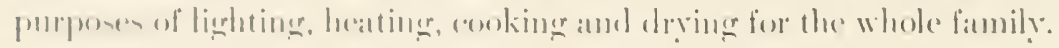

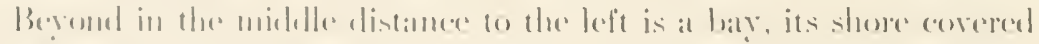

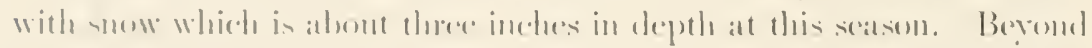

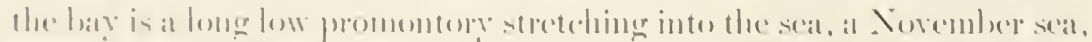

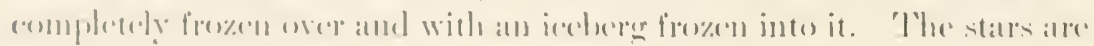

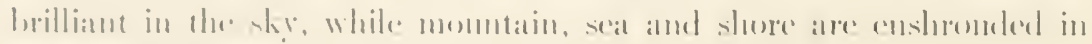

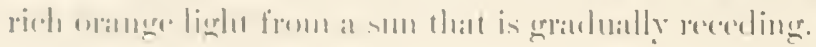

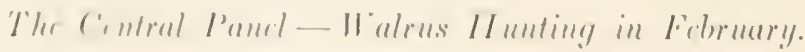

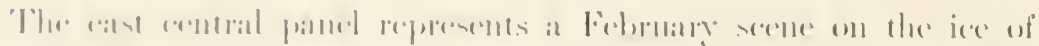

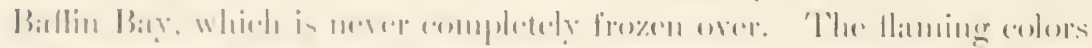

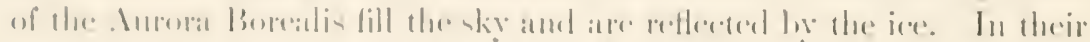

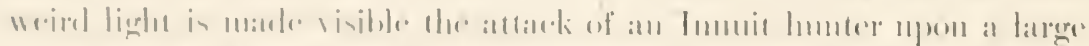

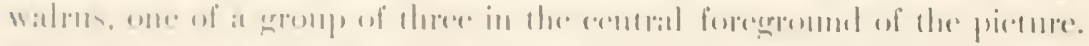

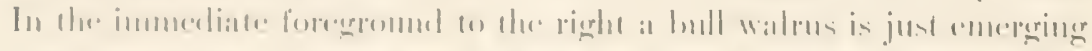

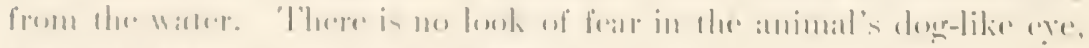

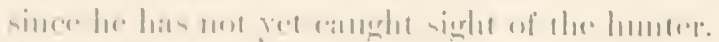

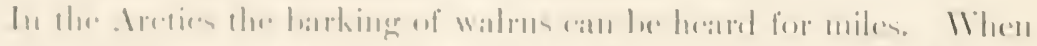

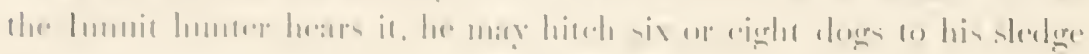




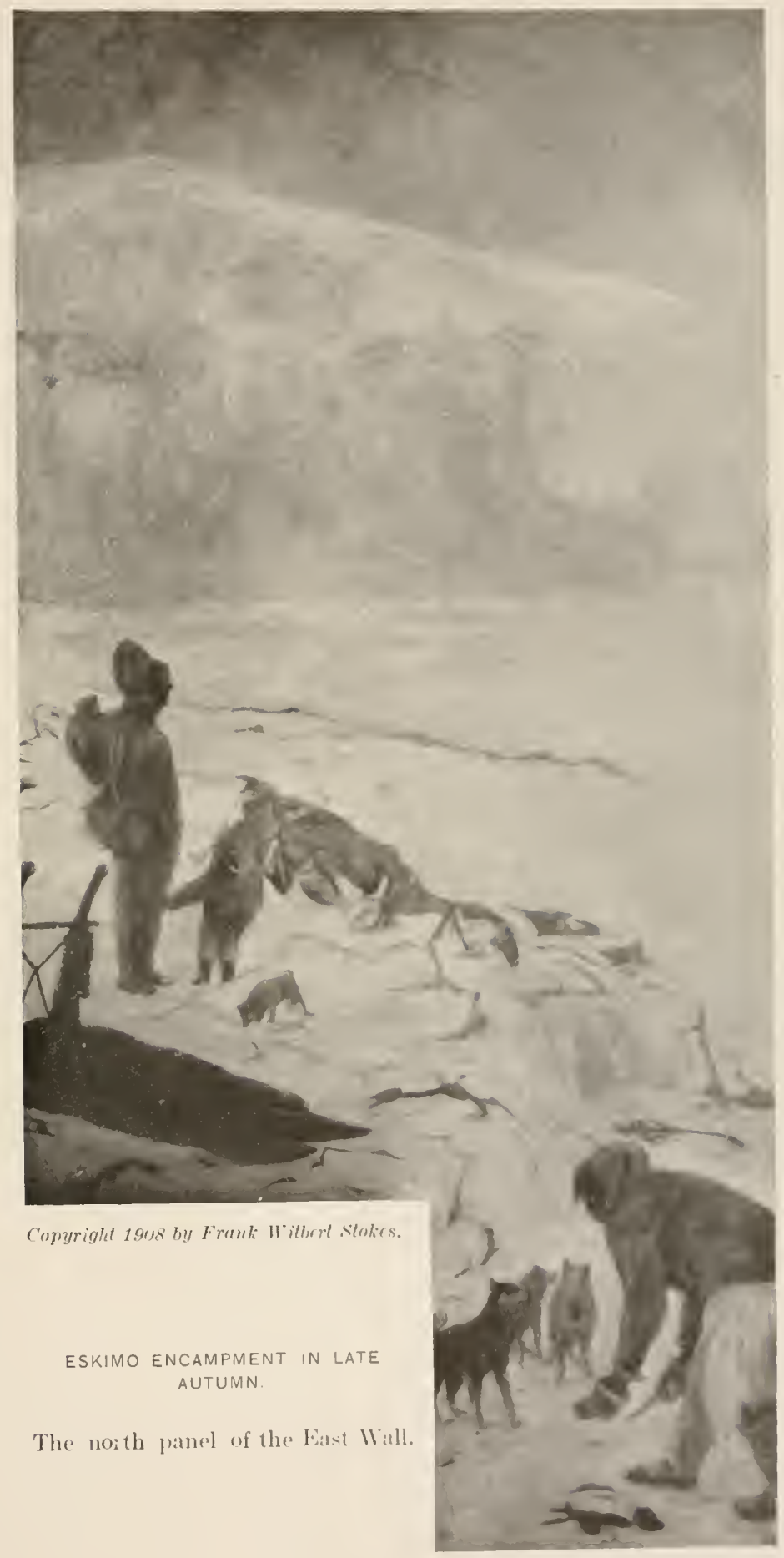




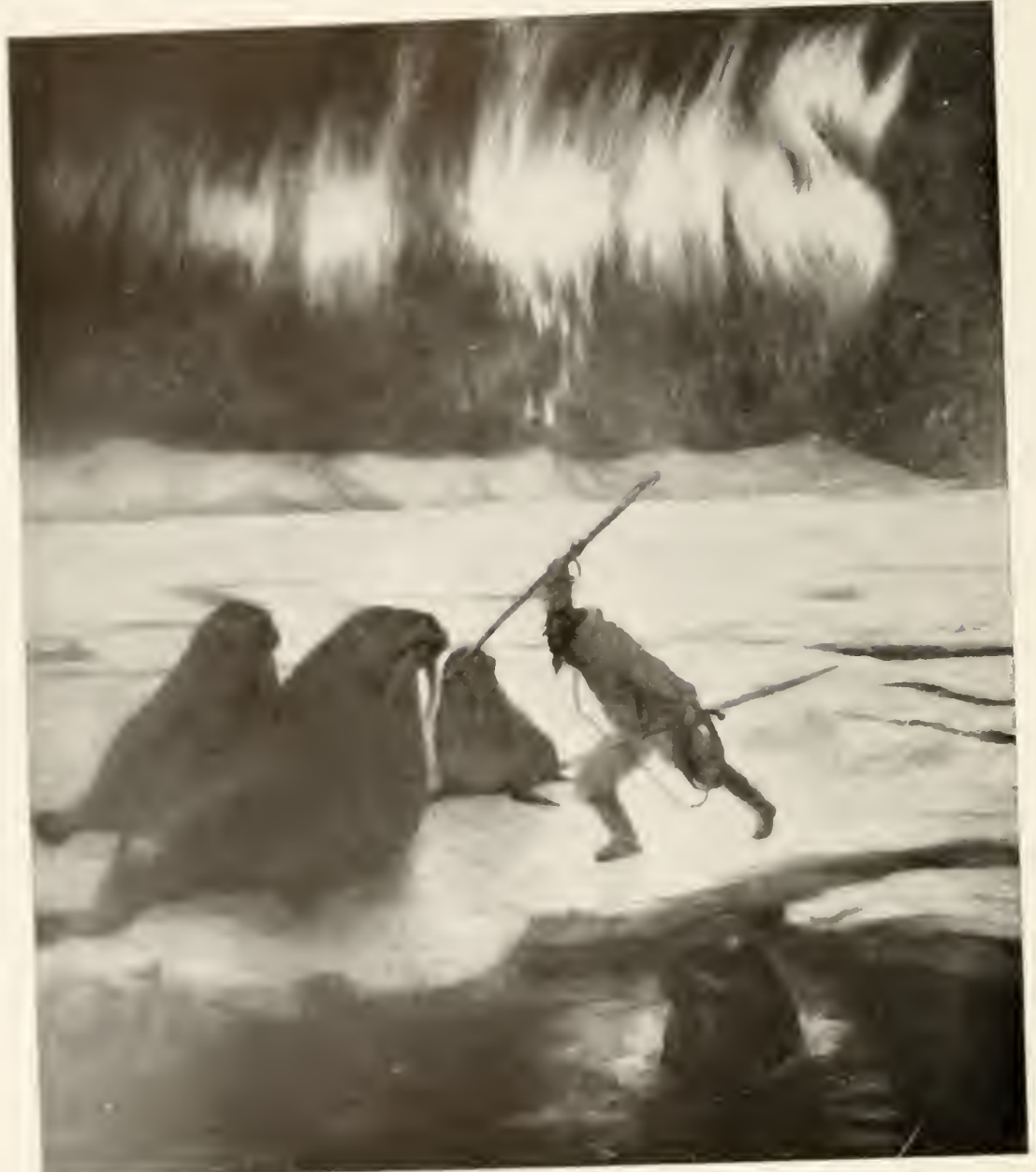

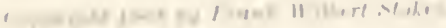

$\therefore A L 16$ MIIN $1 \%$ N THE L,$H T$ OF THE AURORA BOREALIS

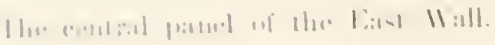

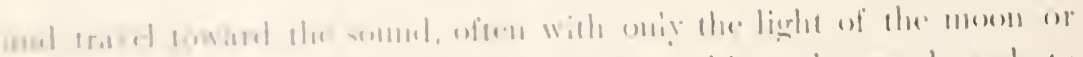

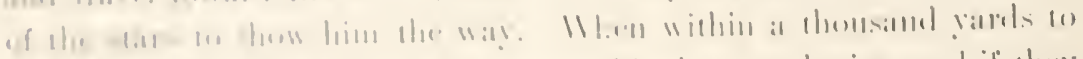

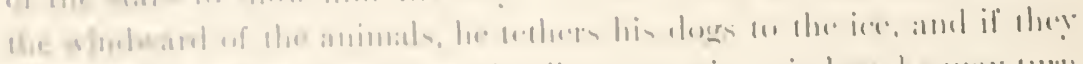

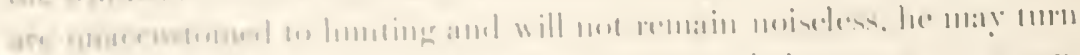

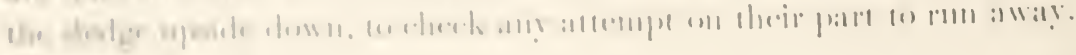


Armed with a stout harpoon and plenty of walrus-hicle line, the Innuit erawls over the ice towird the animals. He conceals himself behind ice blocks or hummocks until the distance between him and the animals is short, then suddenly leaps to his feet, singles out a big bull (as in the painting) and strikes - usually with unerring aim. The whole herd, barking furiously, rushes for the sea. The stricken bull dives, and the walrus-hide line pays out rapidly, but not before the Innuit has deftly thrust his lance, which he carries in his free hand, firmly into the ice. With knee and shoulder braced against the shaft of the lance, he obtains sufficient purchase to play the walrus until the big fellow is so weakened by loss of blood that the hunter can leave his lance to cut two holes in the ice close to the spot where he is standing. Now, whenerer the line is slack, he hauls in a few fathoms, and ruming the noose a couple of times down through one hole and across through the other, obtains a more reliable hold. With the lance now free, he stands over the breathing hole, striking the walrus each time that it rises. When it is finally despatched, he cuts off piece after piece of the meat and seeks his sledge and dogs to carry the spoil home.

Walrus are huge ungainly creatures, weighing upwards of three thousand pounds, but to the nimble Innuit hunter there is usually no difficulty in getting out of harm's way on the ice after he has struck the blow. If, howerer, the iron point slips, or the ice gives way, or if, as the coils of the line are running out, the hunter's legs become entangled, he is quickly dragged down beneath the water to speedy death.

\section{The Third or Southern Panel. Peterawik in Moonlight.}

The third panel represents a winter scene at Peterawik on the shore of Smith Sound. In the foreground at the extreme left is a hunter with sledge and dogs, bringing a load of walrus meat. His snow igloo is at the right, where his wife, carrying a child in her hood, and accompanied by an Eskimo woman, is waiting to welcome him. 'The sei-ice of Smith Sound stretches far to the horizon at the north; the head-line of Cape Alexander is visible in the distance. 'The rocks at the right are characteristic of the west coast of Greenland at this latitude, $76^{\circ} \mathrm{X}$.

In the spring before the ice braks up, the Innuit congregate at Peterawik for walrus hunting. They build their snow igloos on the ice foot, that portion of the seid-ice bordering the land. Here they remain 
hunting, frolicking and feanting in their joyous fashion, until the sun's warmoh las brokes up the iee. Then they travel southward, still over the ice, seme to the settlenents of Inglefiedel Gulf and others even as far is rilje lork.

'HЕ: WE:T W.1L.

\section{The First or Sorthern Pand-Reinder Hunting in Summer.}

The pantinge on the west wall represent bisimo life doring the

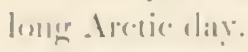

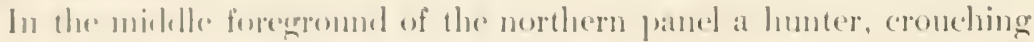

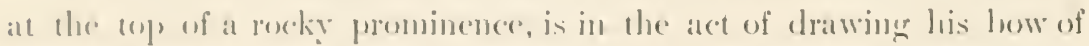

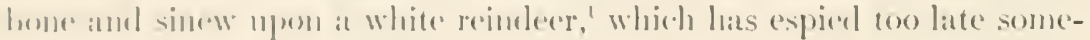

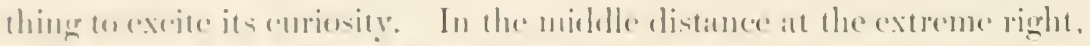
is the antutimation of the larere icelerere of the eentral pamel of the north

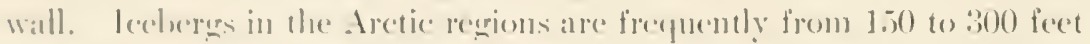

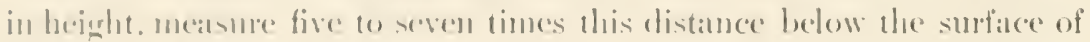
the seat, and sometimes have a lemeth of there miles. Berond the ice-

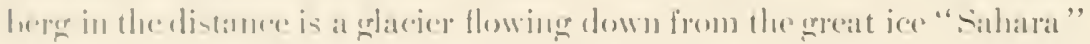
in the interior of Cirecmland, while tu the left is a dark rocky portion of the suburerged lamd.

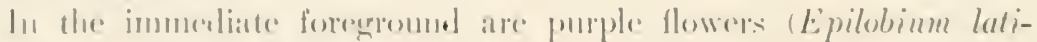
foliume which mente in poekets in the rocks. 'The midelle foreceromel is

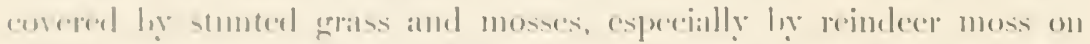

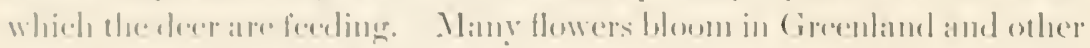

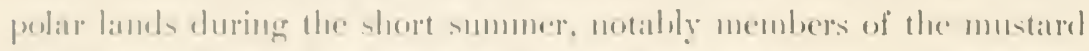
fintuly, and of the pink, rose, sis if rage and grass fandiles. 'There is one

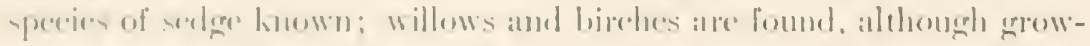

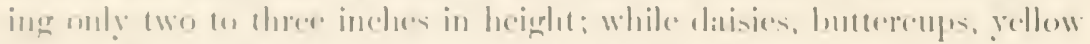

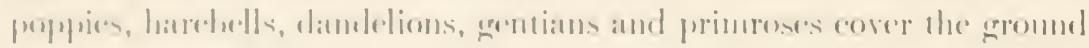

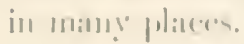

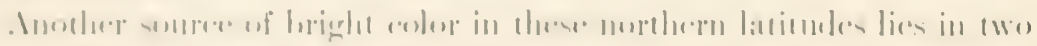

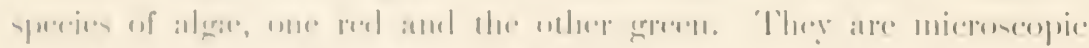

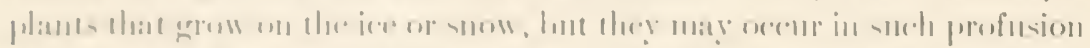

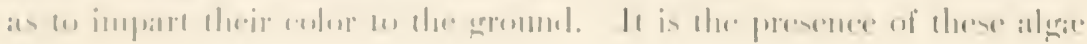

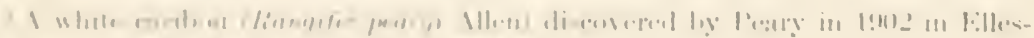

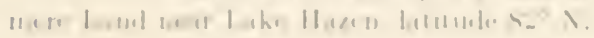




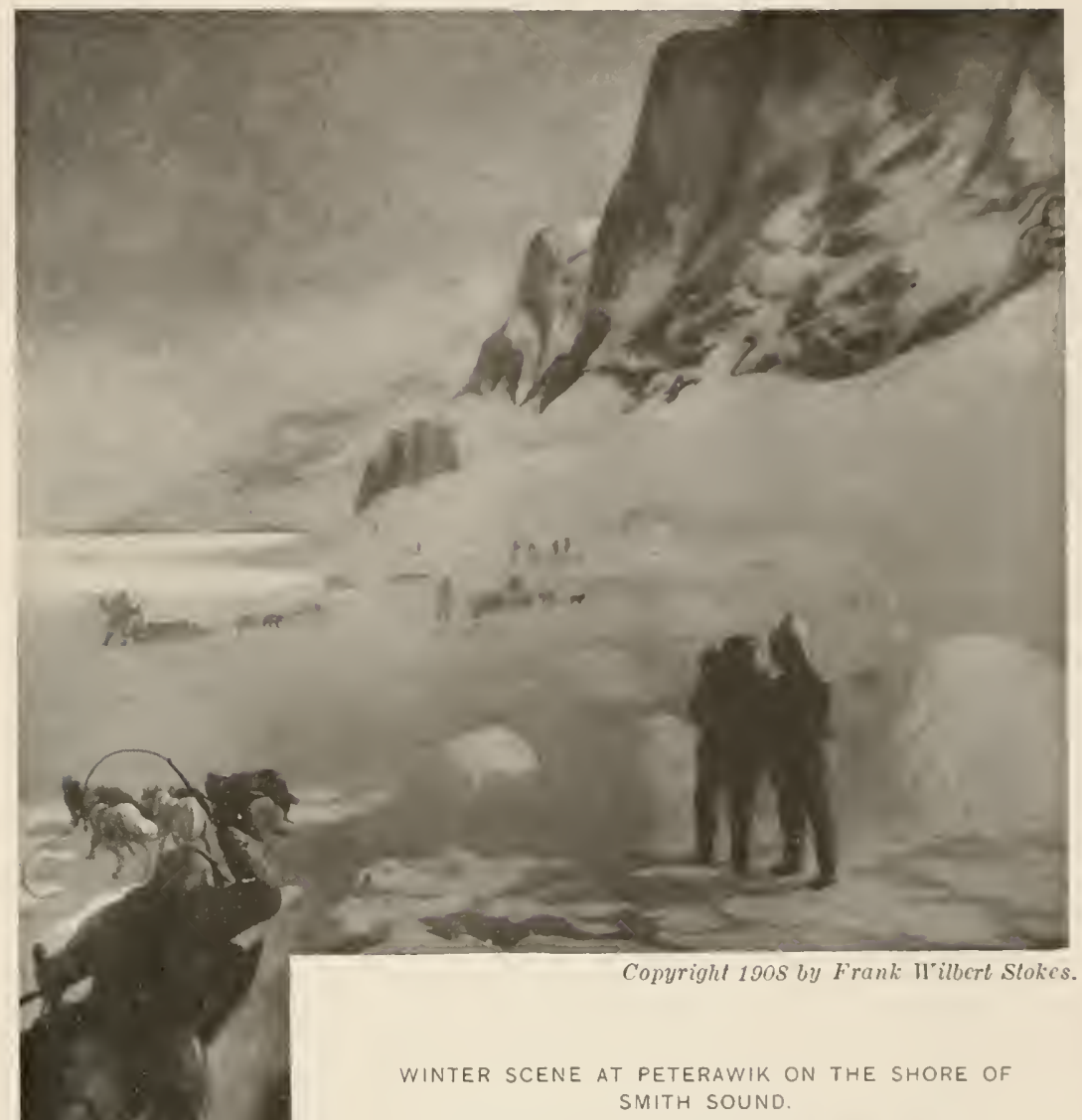

The southern panel of the Wast II all.

that explains the famous "crimson ghatcier" or "rimson snow" near" Cape York.

As to elible plants, there are a few even in this extreme mertherm

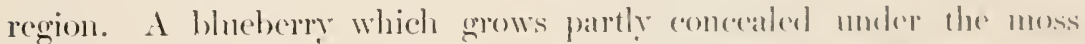
can be seeneel during the greater part of the pratr, and is eaten with redish by the Inmuit. 'There are seromal phants of which the routs, leavers.

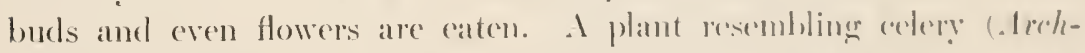
angelica officinalis) is a favorite article of forel. Iredamel moss is also eaten. The chief sources of veretalle fouml, howerer, atre marine. A 


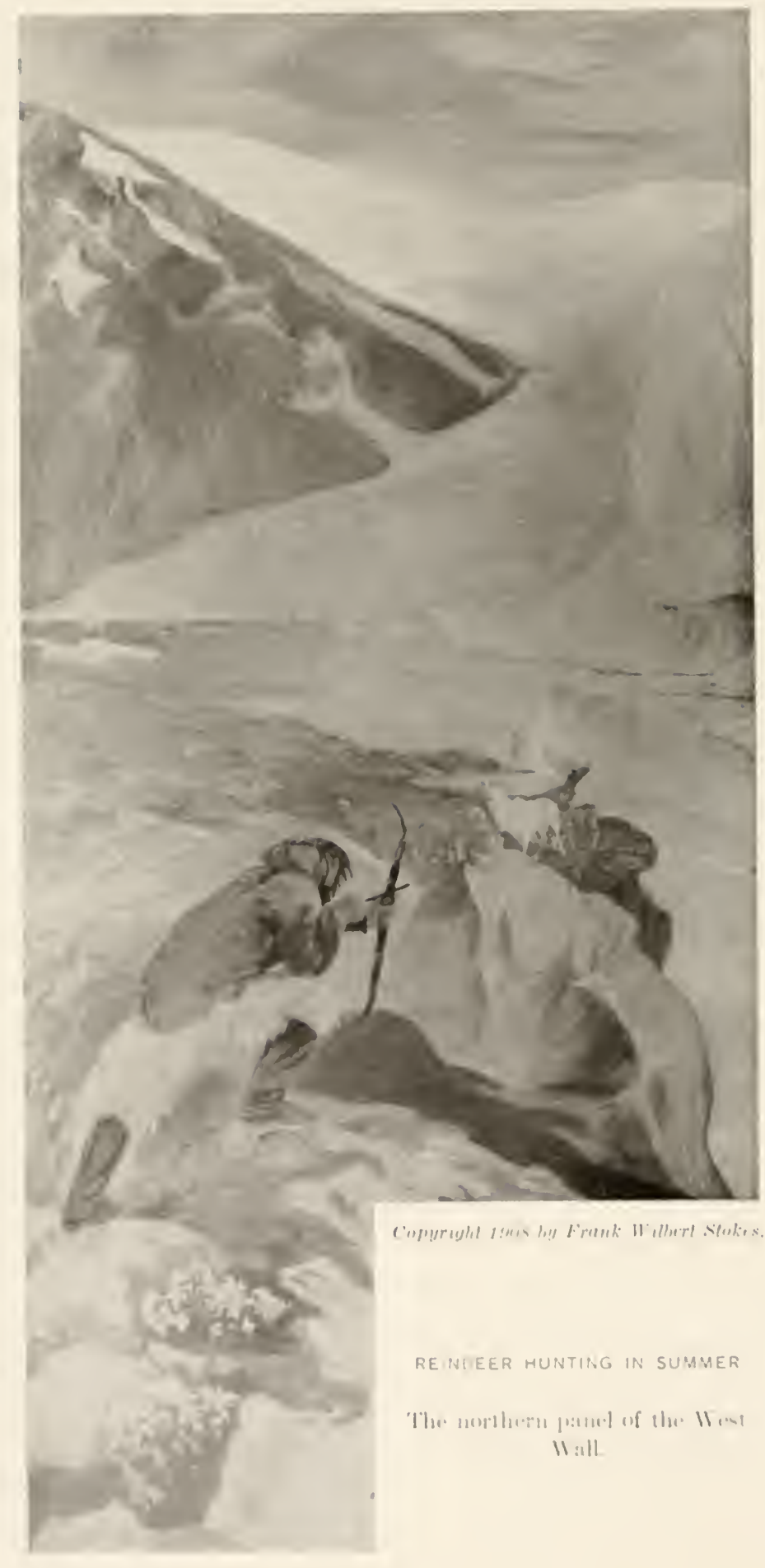




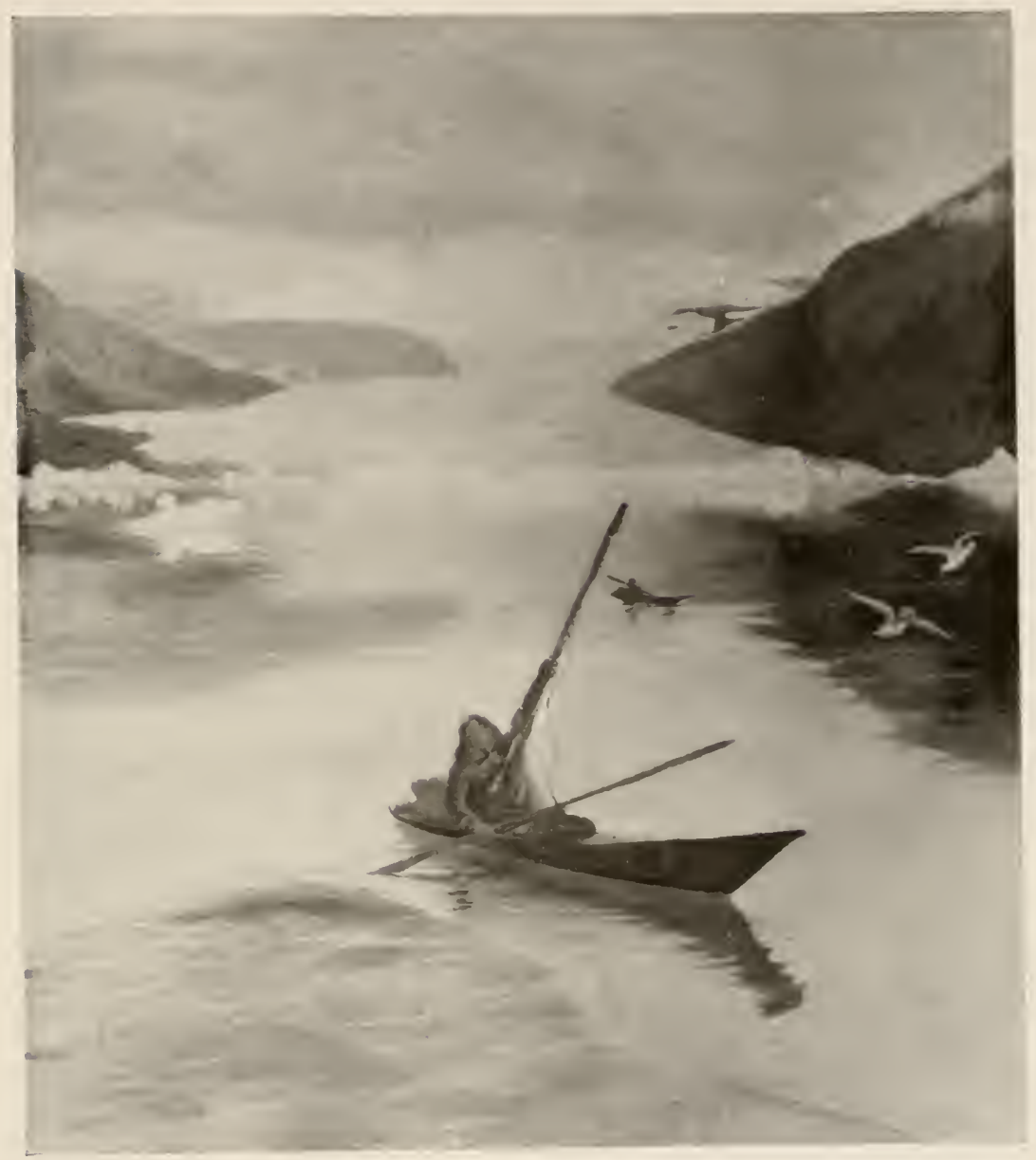

Copyright $190 \mathrm{~s}$ by Frank Wilbert stokes.

ESKIMO IN SEALSKIN CANOE HARPOONING A NARWHAL

The central panel of the llest 11 all.

seaweed used commonly for food is . laria pylaii, chosely allicel to " hlantderlocks," of scotland, and in flavol somewhat like asparatgris.

The Central Panel - Naruhal II unting in sumurer.

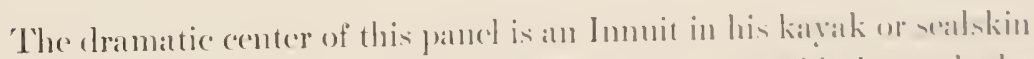

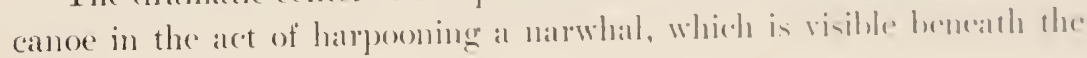


surface of the watere at the left of the boats. 'To the right in the mildle distance are fulmall gulls. In the distance is the great ice river, the Verhoedt alariers.

'The narwhal is an animal ahout which litte is definitely known.

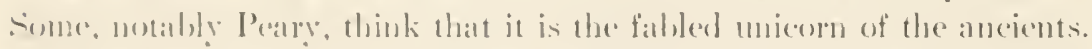

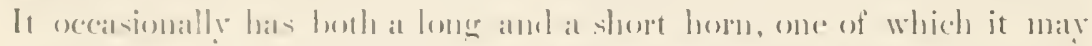

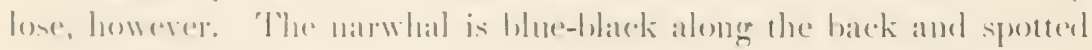

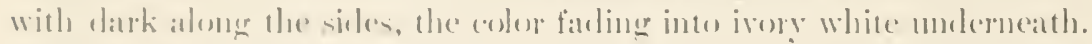

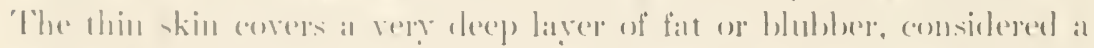

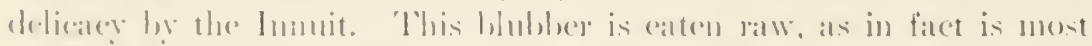

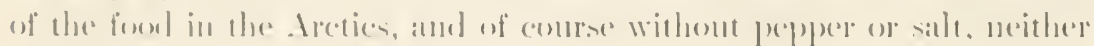
of which is known to the biskimo.

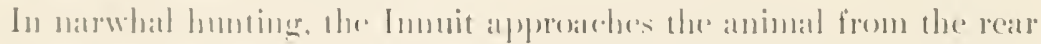

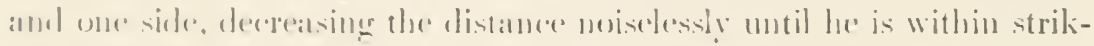

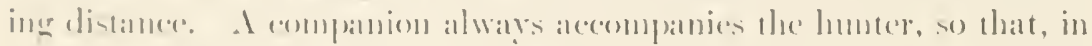

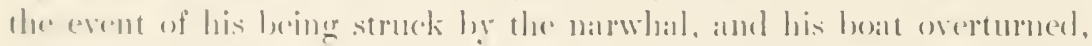

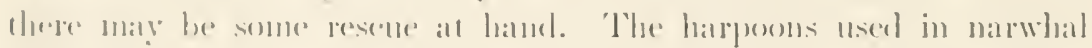

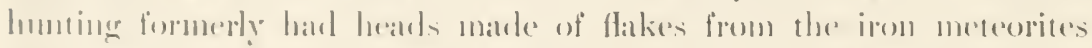
mear citfe lork, lut sime the first quatere of the nimeternth century

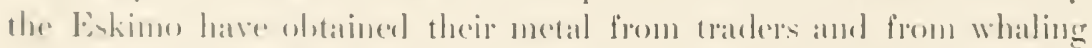

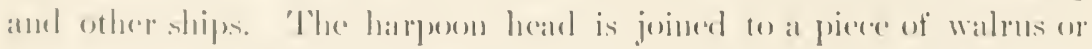
narwhal isory, which fits lowsely on to the ivory and of the shate. 'T'o the center of this harpenen head, is fastemed a line of wallus hide kept

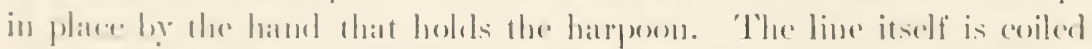

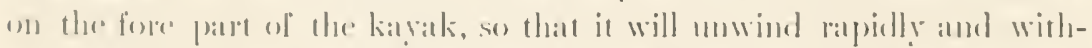

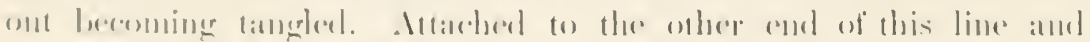

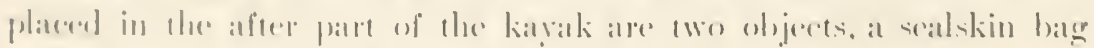

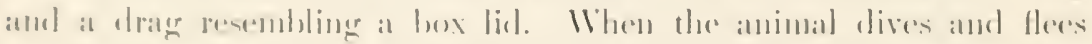

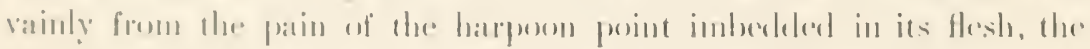

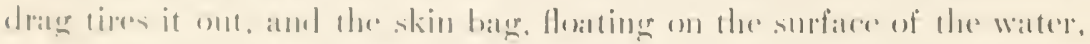

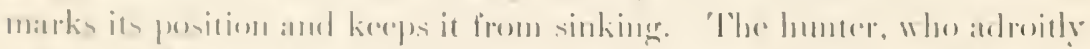

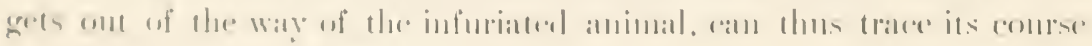
and finally twa it hime.

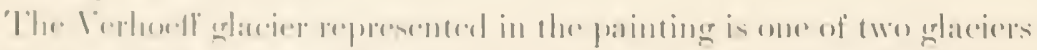

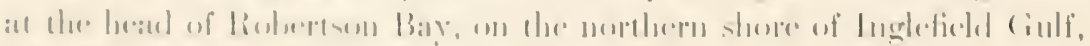

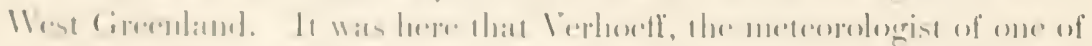

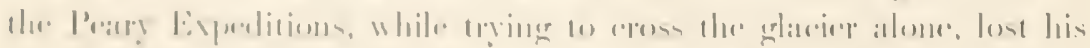

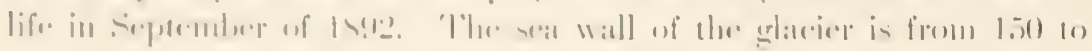

\section{R D 14.8}




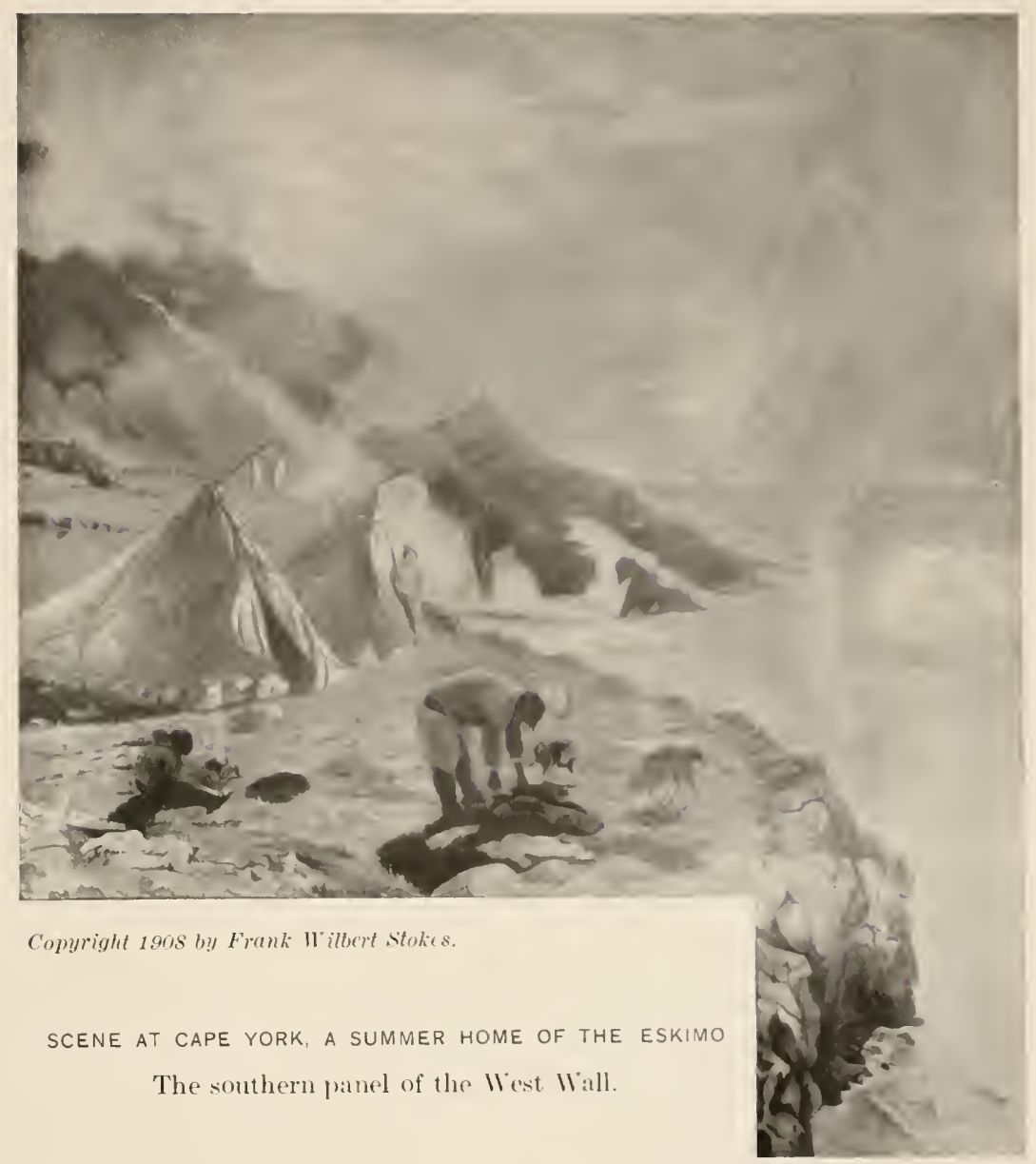

200 feet high, but the ice shelves ont beneath the water, where the buenancy of the sea breaks off parts which float alway als iccherge. 'This birth of icebergs at the water's edgere of al glaciel oftem calleses waves thirty or forty feet in height, miles in extent, and altemderl by volleys of thunderous reports that are terrifying in the eals's of the Lakimo. Fiald of these glaciers is an arm of the inland ice (ap) of Cirecruland, a mighty sheet submerging momutains and valleys to al elepth of 5,000$)$ foet or more. 


\section{The Third or Southern Pand-C'ape Iork, a Summer Home of the Innuit.}

'The serne depicted is alt Calpe York, a summer home of the Innuit, at the head of Metrille Baly. Here the Lmmit, or Aretic Highlander, als he was misnatmed hy sir dames hosen is first met he those visiting the Arcties. The paintingr gives a view of Calpe Sork looking toward the nort!s.

In the foregromel is the camp, where an Imnuit leans over a harpseal which he hats killed and is about to cut up, while his doges are watchumg for some strage ficece of meat. 'This man is clothed in hearskin trousers and a hooded jacket made of about seventy ank skins, the feathers being turned next to the body. He is wearing boots of sealsin.

fo the left in the (amp) is a girl of aldont seren years, painted from

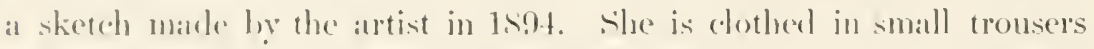
of fox skin and an upper hooded tratrunent, also of fox skin, and wears boots of sealskin, reathing to the thights. She is attending a fire of moss and blubler, wer which blood soup is being prepared, while gratuding from the doegs a piece of meat on the groumd at her righte Behind the grirl are two sealskin tents (tupekhss) from one of which a yommgr womant is emerging.

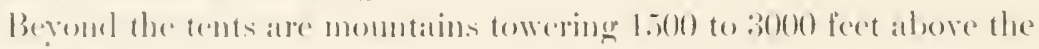

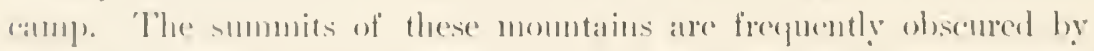

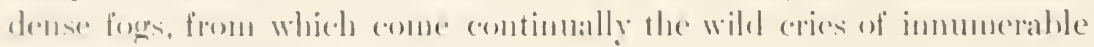
multitules of kittiwal ke grulls and little anks.

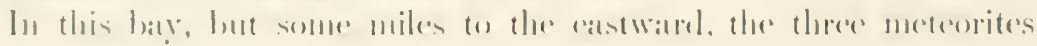

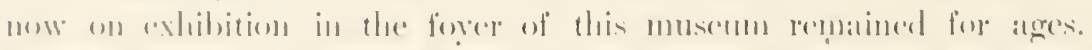

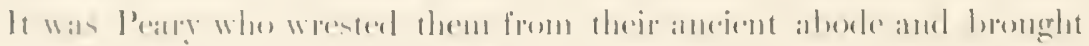

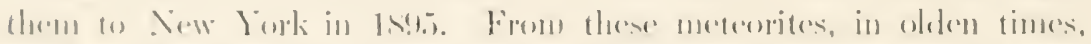

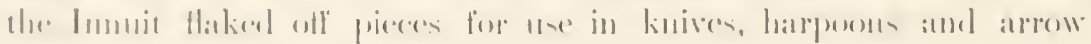

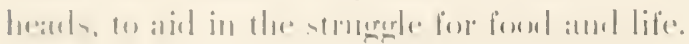




No. 12,- THE COLLECTION OF FOSSLL VERTEBRATES. By W. D. MAT THEw, Pl. D., Associate Curator of Vertebrate Pal:eontology. October, 1303. Price, 10 conts.

No. 13.- A GENERAL GUIDE TO THE AMERICAN MUSEUM OF NATURAL HISTORY. January, 1904. Out of print.

No. 14.- Bhrds' NESTS AND EGgS. By Frank M. Chapman. Associate Curator of Mammalogy and Ornithology. April, 1904. Reprinted, February, 1905. Price, 10 cents.

No. 15.- PRINITIYE ART. July, 1904. Price, 15 cents.

No. 16. - THE INSECT-GALLS OF THE VICINITY OF NEW YORI CITY" By William Beutenaüller, Curator of Entomology. October, 1904. Price, 15 cents.

(Reprinted from The American. I/useum Journal.)

No. 17.-THE FOSSIL CARNIVORES, MARSUPIALS AND SMALL MAMMALS IN THE AMERICAN MUSEUM OF NATURAL HSTORY. By W. D. Matтhew, Ph. 1)., Associate Curator of Vertebrate Palæontology. January, 1905. Price, 15 cents.

No. 18.- THE MOUNTED SKELETON OF BRONTOSAURUS. By W. D Matthew, Ph. D., Associate Curator of Vertebrate Palæontology. April, 1905. Out of print.

No. 19.-THE REPTILES OF THE VICINITY OF NEW YORL CITY. By Raymond L. Ditmars, Curator of Reptiles, New York Zoölogical Park. July, 1905. Price, 15 cents.

No. 20.- THE BATRACHIANS OF THE VICINITY OF NEW YORK CITY. By Raymond L. Ditmars, Curator of Reptiles, New York Zoölogical Park. October, 1905. Price, 15 cents.

No. 21.- THE DEVELOPHENT OF A MOLLUSK. By B. E. DAhlgrex, D. 11. D. January, 1906. Price, 10 cents.

No. 22.- THE BIRDS OF THE VICINITY OF NEW YORI CITY. BY FRANK II. Chapuan, Associate Curator of Mammalogy and Ornithology. A pril-July, 1906. Pries, 15 cents.

No. 23. - THE SPONGE ALCOVE. By Ror IT. IIrser, Assistant Curator of Invertebrate Zoölogy. October, 1906. Price, 10 cents.

(Published as a separate series.)

No. 24.- PERUVian MUdimies. By Cimarles W. Mead, Department of Ethnology. March, 1907. Price, 10 cents.

No. 25.- PIONEERS OF AMERICAN SCIENCE. Memorials of the naturalists whose busts are in the Foyer of the Museum. April, 1907. Price, 15 cents.

No. 26.-THE METEORITES IN THE FOIER OF THE AMERICAN MUSEUM OF NATURAL History, By Edmund Otis Horry, Ph.D., Associate Curator of Ceology. December, 1907. Price, 10 cents.

No. 27.- THE MALARIA MOSQUTTO. By B. E. DAHLgmi, D. M. D. Assistant Curator of Invertebrate Zoölogy. April, 190S. Price, 15 cents.

No. 28. - THE HABITAT GROUPS OF NOIRTH AMERICAN BIRDS. BY Frank M. Cliapman, Curator of Ornithology. February, 1909. Price. 15 cents.

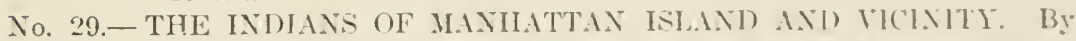
Alanson Skiscer, bepartment of Anthropology. September, 190? Priee, 10 cents.

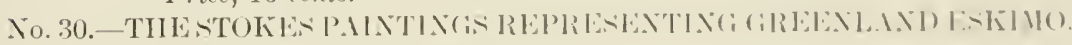
Norember, 1!m!s. Price, somts. 


\title{
The American Pluseum Journal
}

\author{
EDMexd Uts Hover, Ellitor.

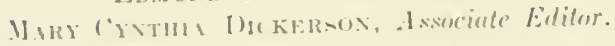

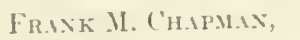

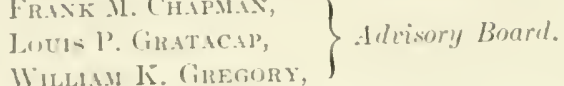

The Juersal is sent free to all Members of the Huseum.

\section{Guide Leaflets published by the}

AMERICAN MLSEUM OF NATURAL HISTORY.

For Sale at the Huseum.

(Issued as supplements to The American Muscum Journal.)

io. 1.- THE BIRD ROCK GROUP. By F. M. Curaparax, Associate Curator of Mammalogy and Ornithology. October, 1901. Price, $10 \mathrm{ccnts.}$

今o. 2.-THE SAGINAW VALLEY COLLECTION. By HI. I. SMIT, Assistant Curator of Archeology. December, 1901. Price, $10 \mathrm{ccnts}$.

No. 3.-THE HALl, OF FOSSI, VERTEBRATES. By W. J). MATTHEW, Ph. D., Assistant Curator of Vertebrate Palzeontology. January, 1902. Out of print.

No. 4.-THE COJlliCTION OF MINERALS. By lovis P. Gratacap, A. II., Curator of Mineralogy. February, 1902. Revised clition, May, 1904. Price, 10 cents.

No. 5.-NoRTH AHERICAN RUMINANTS. By J.A. Allex, Ph. D. Curator of Mammalogy and Ornithology. March, 1902 Reviscd edition, February, 1904. Price, 10 cents.

No. 6.-THE A.COENT IBASLET MAKERS OF SOLTHEASTERX UTAH. 13y Cilongr: 11. l'eppkn, Assistant in Anthropology. April, 1902. Secunul edition, . Iay, 1909. Price, 10 cents.

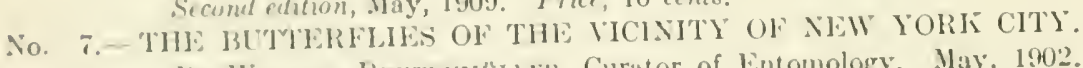

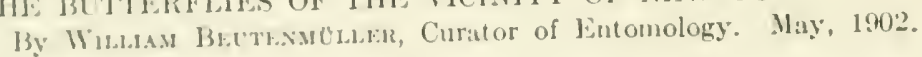
l'rice, 15 cents.

No. 8. - THL Sl:QUOJA. A Historical Review of Biological Science. By Groncie H. Surmwoon, A. I., Assistunt Curator. November, 1902. Price, 10 cents,

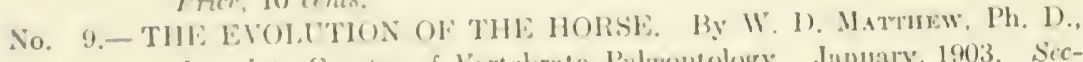
Associate curator of Vertebrate Pabrentologg. January, 1903. Secand adition, May, 1905. Price, 10 cents.

№. 10. - THE: HAWK-MOTHS OF 'THE VICNITY OF NEW YORK CITY.

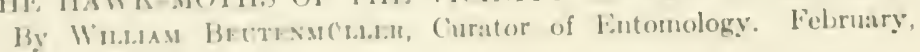
$1 ! k) 3$. Prie, 10 conts.

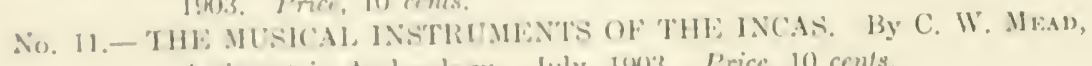
Anistant in Arcluoblogy. July, 1!n)3. Price, 10 cents. 



8.

$c^{4}+8$

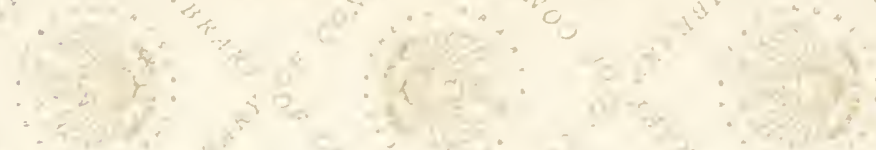

중ำ

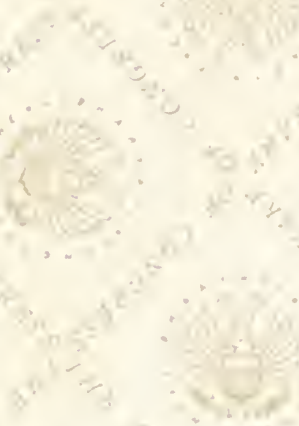

D. $3 c^{2}-1$
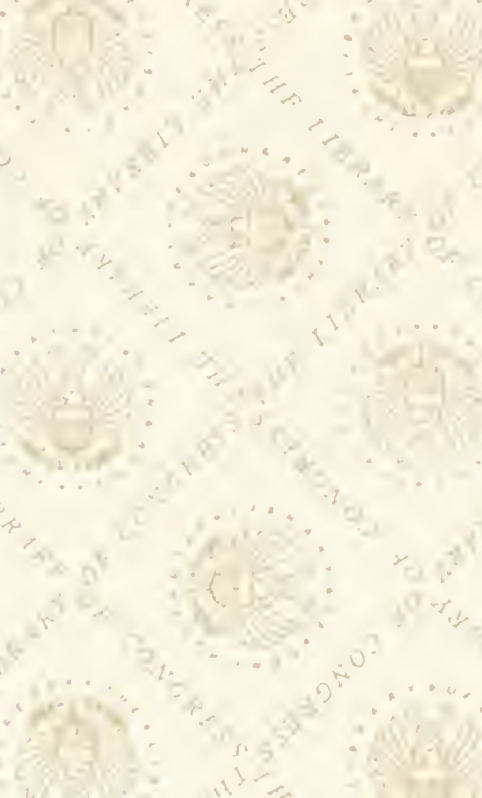

insi: $\frac{-1}{2}$

$(2,-1)$

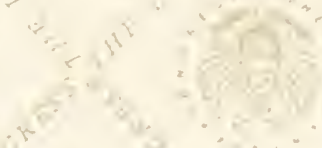

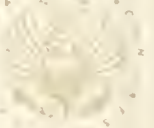

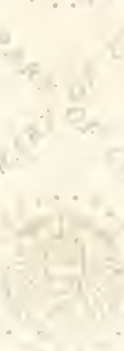

4 in

nis

낮

art

(10)

(5)

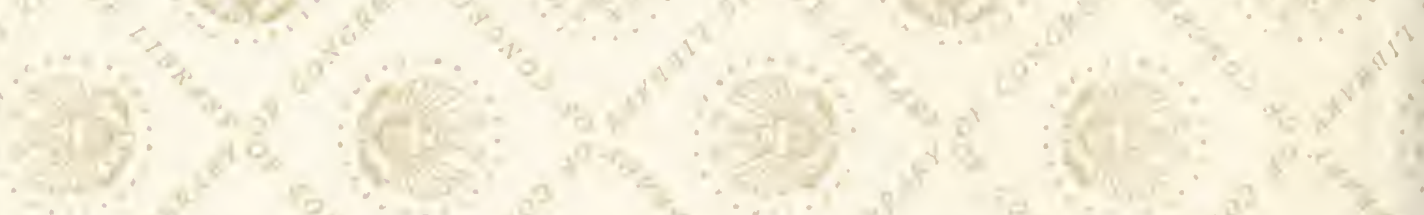
(3) $0 \quad x$ act

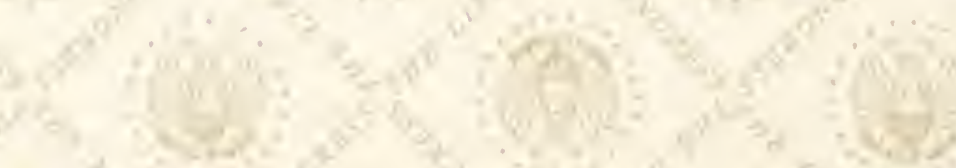

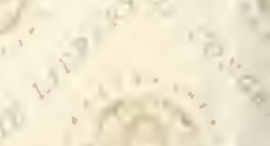




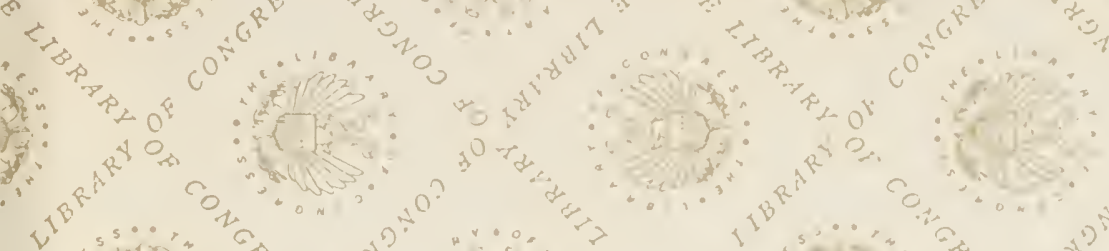
$\frac{x^{3}+x^{2}}{2}$

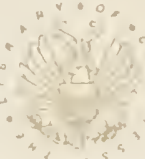

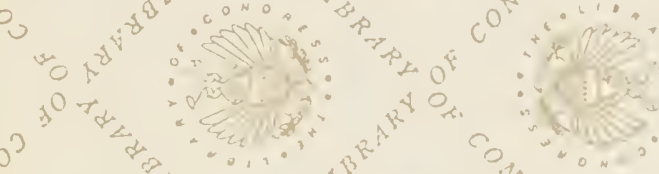

\section{te}
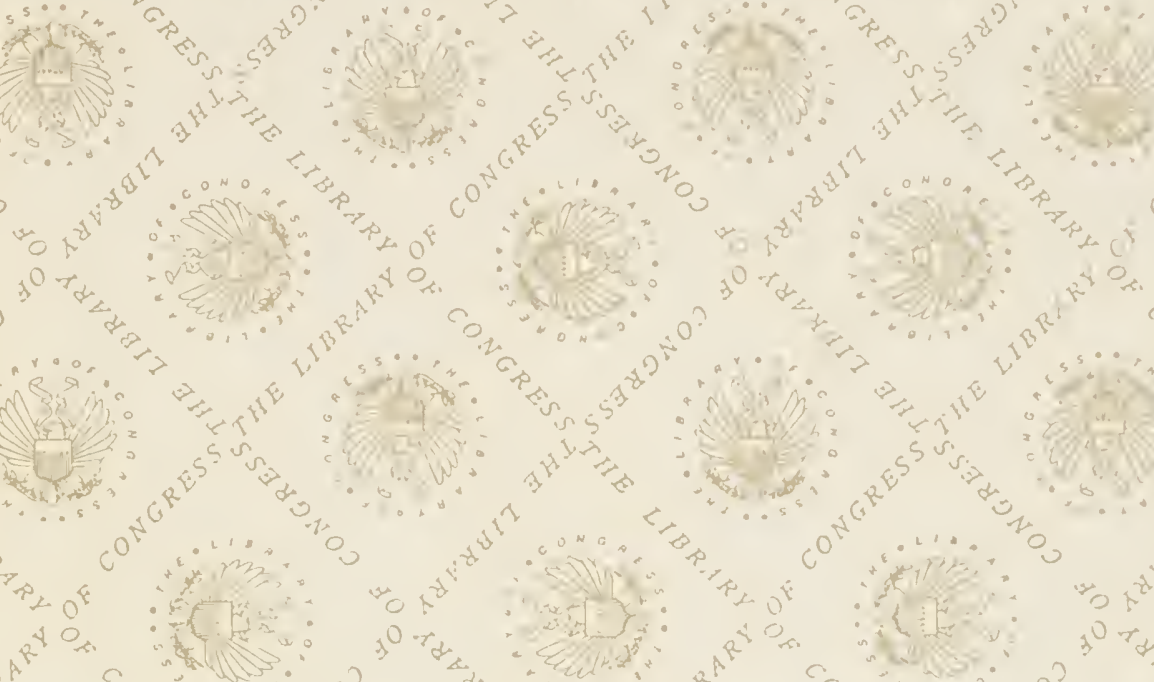

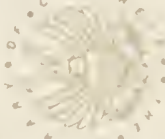
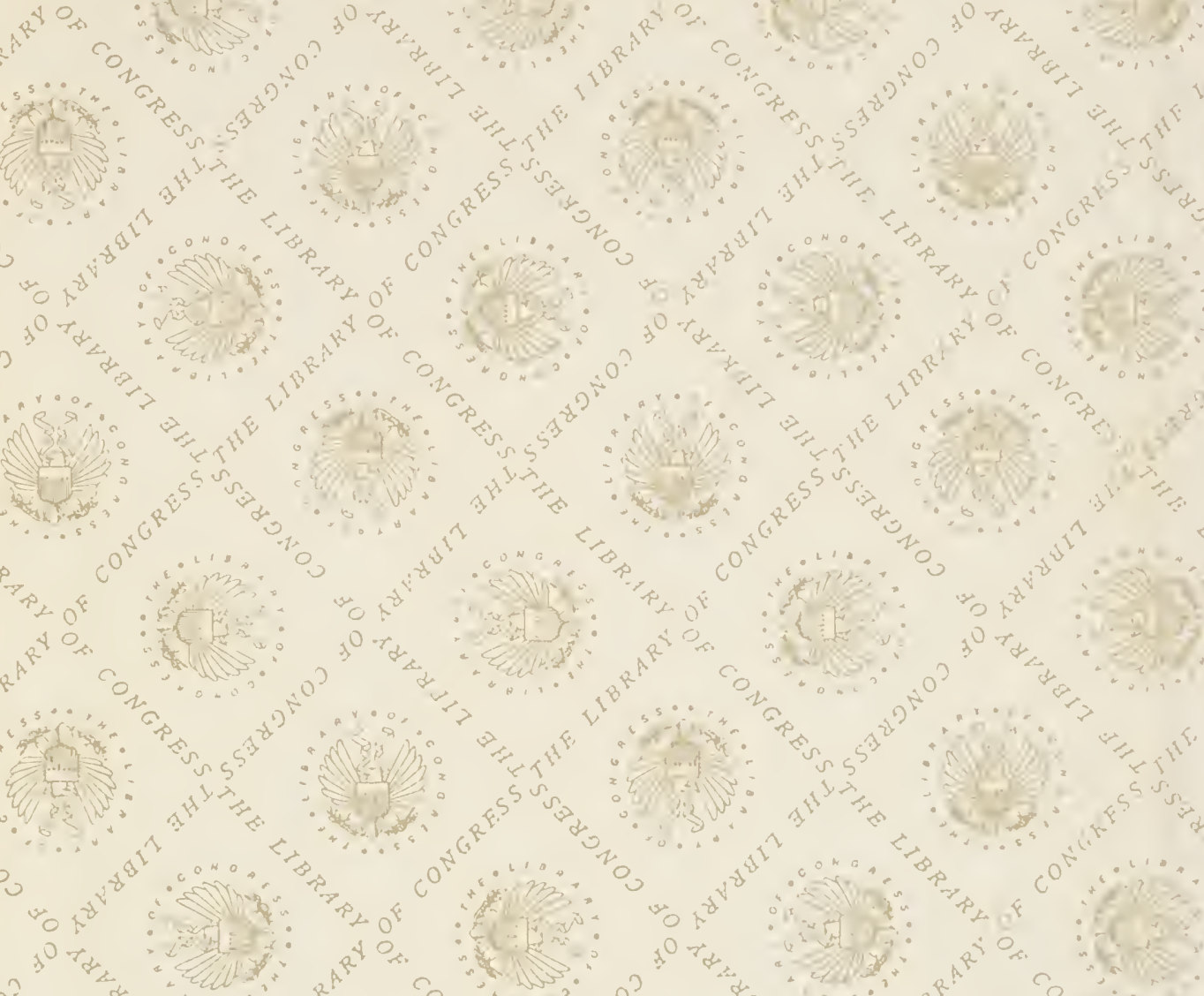

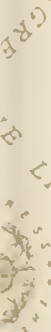
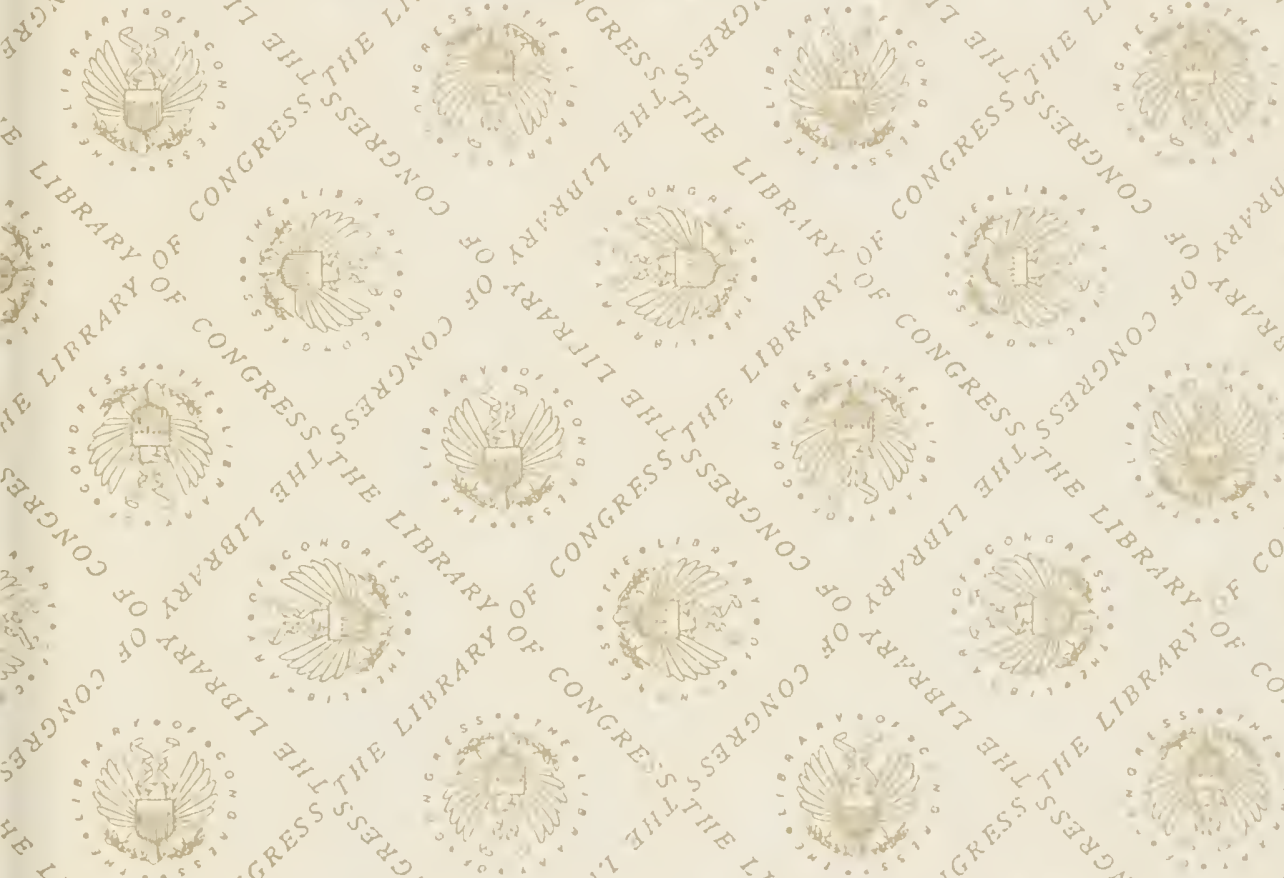

and
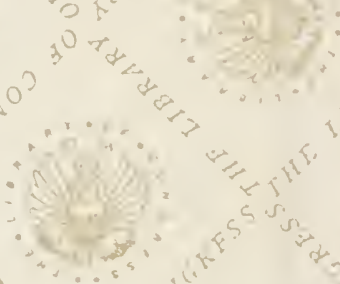

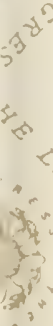
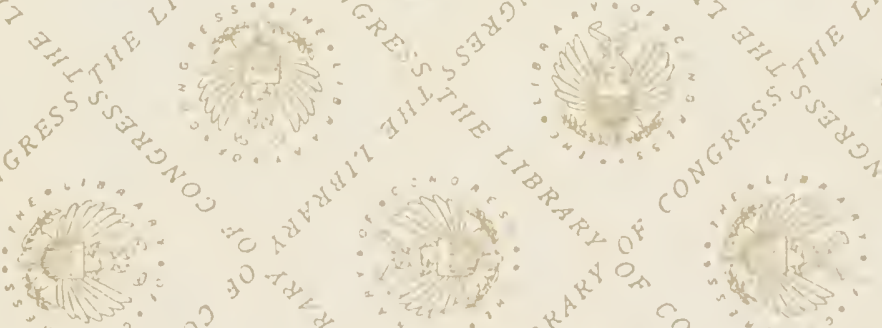

(4)
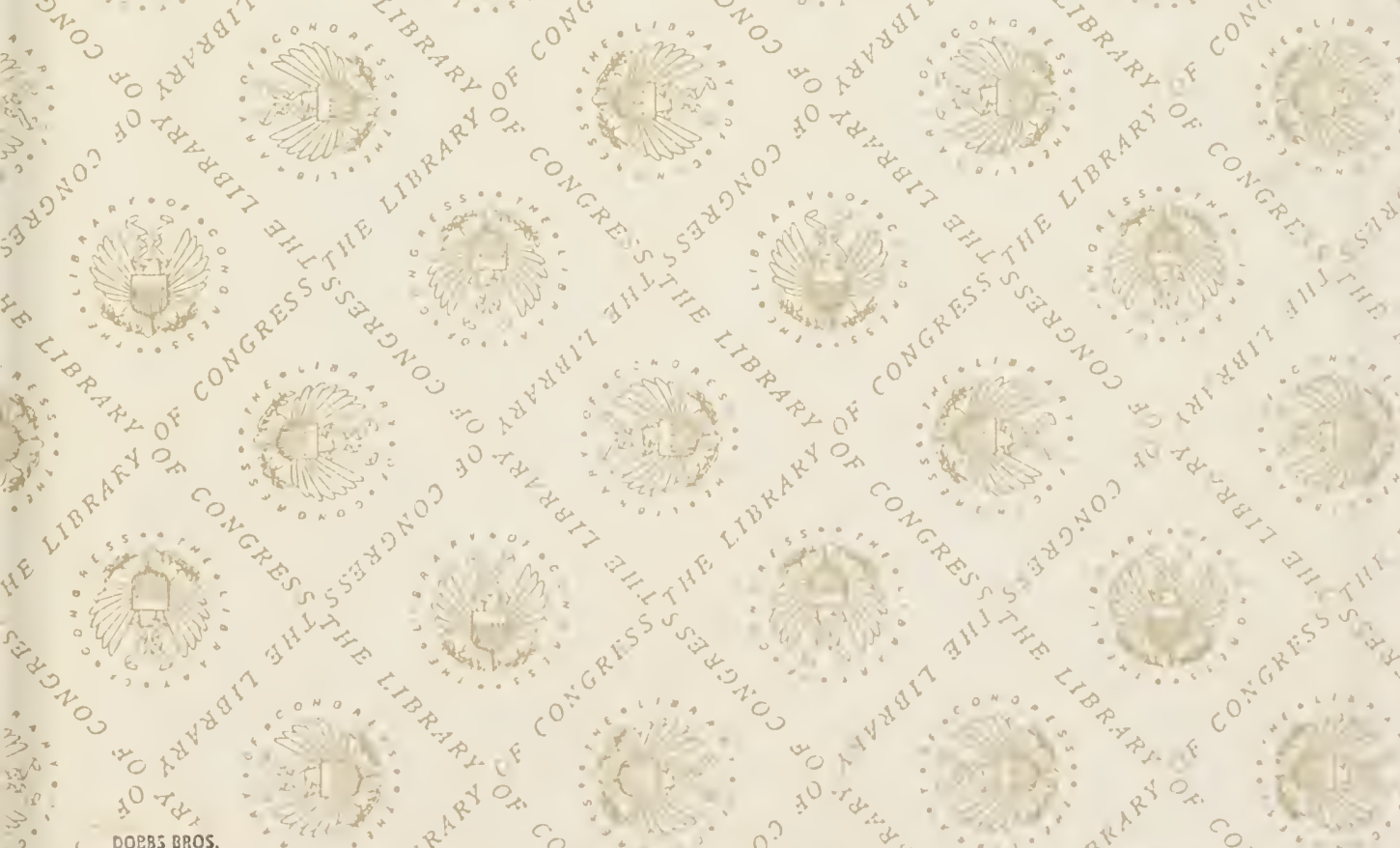

T' DOEBS BROS.

$5^{2} 3^{8}$

SST. AUSUSTINE

FLA.

32084 
